\title{
Corruption Here, Corruption There, Corruption Everywhere: A Framework for Understanding and Addressing Public Sector Corruption in Developing African Democracies
}

\author{
Emmanuel Yeboah-Assiamah (Corresponding author) \\ Department of Public Administration \& Health Services Management \\ P.O.Box LG 78, University of Ghana Business School \\ Legon-Ghana
}

Phone: +2330542038794_ E-mail: yimmanuel@yahoo.com

Kwame Asamoah

Department of Public Administration \& Health Services Management

University of Ghana Business School, Legon-Ghana

\begin{abstract}
Alex Osei-kojo
Department of Public Administration \& Health Services Management

University of Ghana Business School, Legon-Ghana
\end{abstract}

Accepted: August 08, 2014

Doi:10.5296/ jpag.v4i3.6406 URL: http://dx.doi.org/10.5296/ jpag.v4i3.6406

\begin{abstract}
Corruption exists in all political jurisdictions globally, but it is believed to be more pronounced in transitional democracies especially African countries. Due to the extent of corruption in African countries, scholars and practitioners in the fields of public policy and development studies suggest that corruption has significantly undermined, and continues to undermine development on the continent. Using Africa as a case study and selected theoretical models, this paper views corruption as a transaction process and provides a model to explain how the transaction occurs between the actors involved. It also explores how corruption diminishes efforts towards the development of Africa, and proposes a comprehensive framework that can be adopted to curb the canker of corruption in Africa. The
\end{abstract}


study adopted the content analysis technique within qualitative study. It thus, draws extensively on existing literature available in peer reviewed articles, conference and government reports, books and magazines. Among the key findings of the study are that; corruption is a two-way affair, which manifests in some sort of demand and supply. It was also found out that the prevalence of weak bureaucratic institutions and systems (context) and the manner of how transactions are conducted (process) all contribute to promotion of corruption in developing African countries. In order to address the problem of corruption, the study recommends the adoption of a holistic approach, which involves a strong political will to enforce law and order, strengthening state institutions to detect, expose and prosecute culprits irrespective of their status and political affiliation. The paper also suggests that bureaucratic and political elites should take the lead in fighting corruption by conducting themselves in a manner that will inspire trust and confidence in the entire political system.

Keywords: Corruption, transaction, underdevelopment, developing countries, public sector

\section{Introduction}

Nearly all governments, globally, suffer from the sting of corruption which destroys human lives, and sabotages the efforts of communities and institutions in the pursuit of development (Transparency International, 2013). Nonetheless, corruption is believed to be more prevalent in underdeveloped countries often with weak democratic institutions; this eventually places such economies in a quagmire of poverty (The World Bank, 2007; Gyimah-Boadi, 2002; UNDP, 2008; Myint, 2000; Transparency International, 2013). For instance, Myint (2000) observes that "corruption is most prevalent where there are other forms of institutional weaknesses, such as political instability, bureaucratic red tape, and weak legislative and judicial systems" (p. 56). He further argues that corruption and institutional laxities are involved in a complex and interlinked web of relationship since both feed into each other and, therefore, two sides of the same coin. This point has similarly been advanced by Blechinger (2005, p.28) that "party corruption is especially problematic in newly democratizing and developing countries where political and economic institutions are not yet secure". It is therefore, not surprising that the Transparency International (2011), observed that of the 183 countries and territories assessed on the corruption ladder, North Korea, Afghanistan, Myanmar and Somalia were found to be the most corrupt.

Despite efforts by the advanced economies to assist African countries through aid, grants, and institutional reforms, African countries are still faced with public sector corruption which tends to derail efforts at growth and development. Corruption is known to "undermine governance, economic growth and ultimately the stability of countries and regions" (Spector, 2005, p.7). Some scholars argue that "evidence from across the globe confirms that corruption hinders economic development, reduces social services, diverts investments in infrastructure and social services and impacts the poor disproportionately" (Khramkin, 2007, cited in Osei-Tutu et al., 2010, p.237). Mauro (1998) notes that there is a depressing correlation between corruption and growth; and evidence suggests that the former adversely reduces the growth and quality of life. Based on these discussions, Osei-Tutu et al. (2010), 
suggests that international institutions such as the World Bank (2003) cite corruption as one of the formidable obstacles and impediments to economic and social growth in developing countries. On this basis, developing countries must reckon that, in order to develop and to guarantee quality lives to its populace, it is imperative to diagnose the root causes of corruption and adopt holistic measures to curb the menace.

Public sector involvement in the economy has been argued by many scholars as a means to cushion the citizens against private sector exploitation. Conventional knowledge reveals that states intervene in the economy to prevent capitalist exploitation and, therefore, people look up to the state for safe haven. Leftwich (2005), observed that "the state played a central role in the critical early stages of the industrial development of the Organization for Economic Co-operation and Development (OECD) countries, and indeed most of the now developed and some of the successful developing countries in the second half of the $20^{\text {th }}$ century have all shown the importance and effectiveness of the state, especially, towards catch-up development" (p.53).

It is, nonetheless, paradoxical that the public sector officials who are entrusted with state authority to work towards development and to protect citizens against private sector exploitation rather tend to misuse their power and authority to "abuse" citizens and to derail their countries' development effort. One manifestation of abuse of power is the level of ethical decadence in the public sector of developing countries. This level of deterioration of ethics among African public officials has succinctly been described by Shellukindo and Baguma (1993) that, the state of deterioration has worsened to the extent that principal officers in charge of finances have metamorphosed into 'thief accountants' while managing directors are now 'damaging directors' in contemporary Africa and other developing countries.

Given the extent of corruption in developing countries, which was termed as "an eruption of eruption" by Galtung (2001, p. 191), efforts towards development are greatly hampered. For instance, Rose-Ackerman (1999), suggests that corruption has a propensity to lead to underdevelopment of states since it has the ability to cause adversely a limitation in such countries' share of the flow of Foreign Direct Investments (FDI) and the likelihood that the little aid programs and grants would be abused and misused, thereby, having little or no positive outcomes on targets and goals. She concludes that "if government performance does not improve in many states; programs designed to help the poor, improve the natural environment and stimulate economic growth will have little impact and risk inflicting harm" (ibid, p. 299).

In the wake of widespread corruption in Africa and its far-reaching consequences on development, a study that seeks to analyze the multi-dimensional nature of corruption is thus relevant. The main purpose of this paper is to examine the fundamental causes of corruption, as well as its impact on development in developing economies. The paper is organized into five main sections. The first section presents the introduction to the study; it defines the problem to be addressed and also highlights the objectives of the study. Section two discusses the methodological approach that was adopted in carrying out the study. The third section is a 
discussion of the theoretical and conceptual framework within which the study was positioned. The fourth section reviews relevant literature and provides an analysis of data. The final section provides conclusion of the study and recommendations to address the canker of corruption in developing African economies.

\section{Methodology}

The study adopts the retrospective literature analysis of qualitative research approach, which draws extensively on existing literature and secondary sources in explaining and exploring the phenomenon of corruption. According to Cresswell (2013, pp. 47-48), 'we conduct qualitative research because a problem or issue needs to be explored; we also conduct qualitative research because we need a complex, detailed understanding of the issue.' The study draws extensively on several secondary sources of data including magazines, newspapers, scholarly books, journal articles and reports to analyze and explain the problem of corruption in Africa, in order to make the relevant conclusions and recommendations.

The paper adopts the narrative analysis technique to analyze data. This technique refers to the style of presenting data analysis in the form of a story, explaining data in the terminology and concepts of the subjects under study in order to capture the rich, concrete detail of the data obtained (Cresswell, 2013; Neuman, 2007)

\section{Theoretical framework}

This study is situated in the rational choice theory. This theory is also referred to as the public choice theory. The rational choice theory fundamentally assumes that individuals are fundamentally egoistic and self-seeking who will only enter into relationship or transaction based on rational calculation of benefits and costs. The theory assumes that individuals act to benefit themselves and not society per se. From the perspective of this theory, public servants work to advance their own interest through a myriad of ways such as forging documents, underestimation and overestimation, taking bribes or stealing from the state coffers. Zey (1992), analyzing the works of Coleman (1990, pp.13-19; Friedman and Hechter, 1988), observes that the central thesis of the rational choice theory depicts that "social interaction is basically an economic transaction that is guided in its course by the actors' rational choices based on rigorous calculus approach; humans, or man of neoclassical economic theory and its rational derivatives are selfish and greedy, or at least exclusively self-interested" (Zey, 1992, p.2). This calls for the establishment of effective mechanisms to monitor man's activities especially individuals in authority who wield public trust (Zey, 1992; Coleman, 1990; Downs, 1966; Buchanan \& Tullock, 1962).

This rational choice theory was adopted for the study because it is applicable to the behavior of individuals who use their authority and power to advance their personal interest. The theory explains why some public officials abuse public trust by engaging in corrupt practices that undermine the efforts of overall national growth and development. 


\subsection{Conceptual Framework}

A concept is an image or symbolic representation of an abstract idea. It is the researcher's own position or perspective on the problem; and gives direction to the study. Corruption has been conceptualized from different perspectives, and it is worth analyzing some of the perspectives in this study. Some scholars have theorized the concept from the transaction perspective, involving two or more parties. From this perspective, it could be inferred that corruption involves parties who have some agenda to pursue and in the end each partner gains satiation from their actions. This has been observed by Aleman (2004), that "the person corrupting and the person being corrupted had to have agreed to do something illegal; only in the case of such a conspiracy was bribery assumed to have taken place, often the corrupters and the corruptees act according to double standards. In all their dealing they are very much aware that the public detests such transaction, "that is why they keep them secret" (p. 30). In effect, corruption is a transaction process or exchange process that occurs in the "black market" or "blind spot" of public offices.

From that same perspective, Ryvkin et al. (2011), modeled bribery/corruption as a bargaining between private citizens and public officials within a society. They viewed overall corruption in the society as the ratio of citizen-official dyad who engages in bribery; they however, introduced the variables of uncertainty and how each party perceives the other's level of compromise or corruptibility. These scholars conceptualized "corruption as a frequency-dependent phenomenon subject to strategic complementarities, resulting in multiple bilateral bargaining transactions between citizens and public officials whose total costs associated with corruption are determined endogenously by the proportion of successful corrupt transactions in the society"(p.2).

To them, the only variable that determines the frequency or occurrence of corruption depends on how clients or private citizens perceive a particular office, institution or official to be morally or ethically deranged; the more they are certain of ethical derangement, the more they are likely to offer such transactions or items to advance their corrupt practices.

Similarly, Barr and Serra (2005), designed and conducted a bribery game which simulates petty corruption as a barter between clandestine individuals and public officials in which the former must decide how much to offer the latter as an exchange for a preferential service, such as "a reduction in tax, preferential treatment in a court hearing, or speedier admission to hospital" (p. 3.) In a similar vein, the public official has to decide whether to accept and if so, how much to accept as a bribe. It might at times start from the other direction and whichever way it takes, "if a bribe is offered and accepted, the briber-bribee pair benefit, while other members of society incur a cost" (ibid, p.3). They came out with a similar simulation in 2007 where this time the 'public servant' demanded a bribe in exchange for a corrupt service and the "private citizen" had to indicate which, if any, bribe amounts he or she would be prepared to pay. The findings from these studies have led to the conclusion that the prevalence of corruption could be initiated by a private citizen/organization or public official whilst the other party must show interest. 


\section{Macrothink}

From the foregoing analyses, it can be deduced that corruption can be conceptualized as: an economic transaction, game, or process, context-dependent and involve actors (Kaufmann \& Vicente, 2011; Ryvkin et al., 2011; Cuervo-Cazurra, 2006; Ayee, 2000; Weitzel \& Berns, 2006). For instance, Ryvkin et al. (2011), conceptualized corruption as "a frequency-dependent phenomenon subject to strategic complementarities, resulting in multiple bilateral bargaining transactions between citizens and public officials whose total costs associated with corruption are determined endogenously by the proportion of successful corrupt transactions in the society" (p.2). The context of public administration in developing countries provides a fertile ground for such transaction as shown in the figure below.

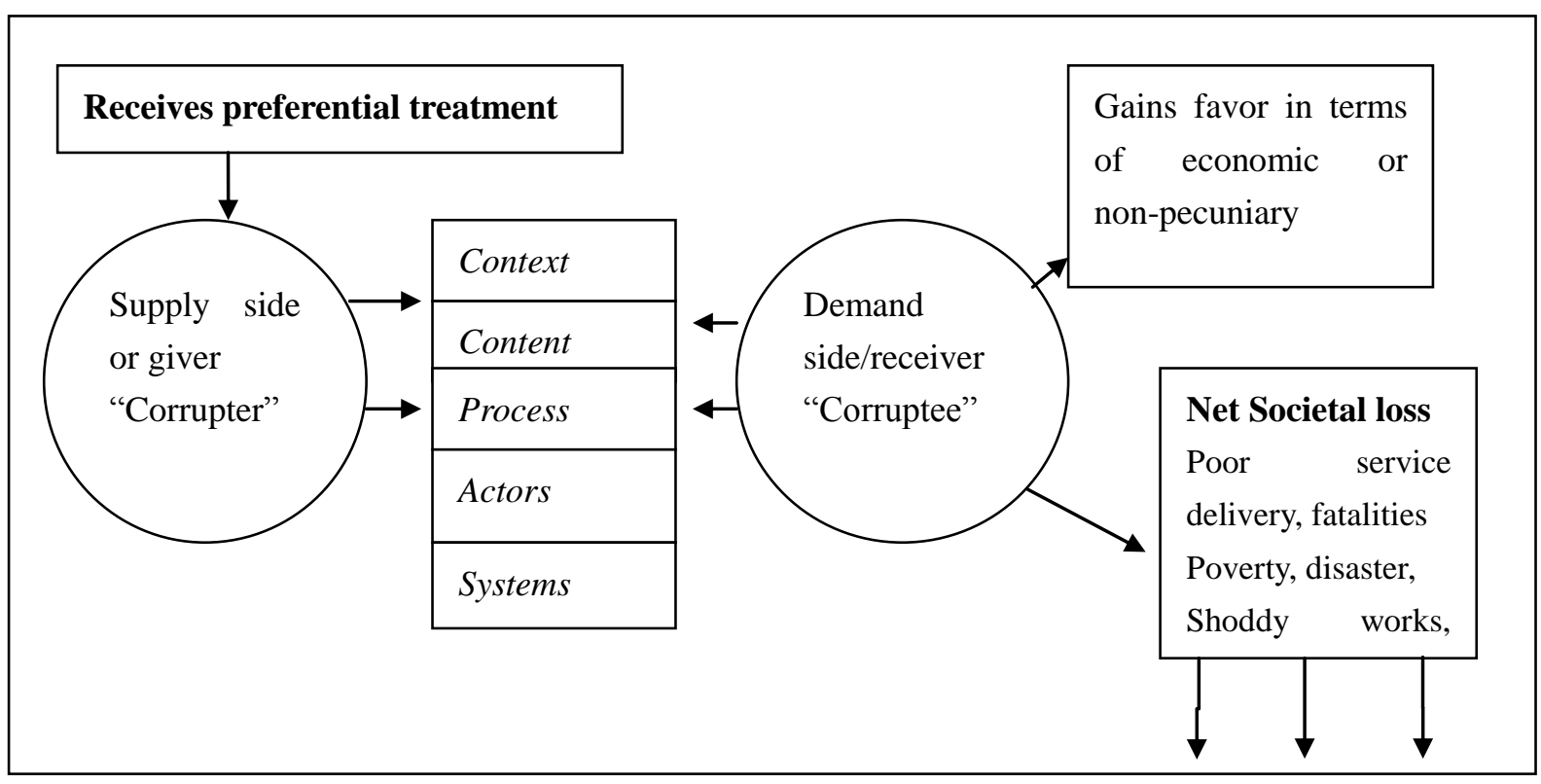

Figure 1: A transactional model of corruption

\section{Source: Authors' construct}

According to the transactional model, corruption is the result of a transaction between actors who share a relationship. In this relationship, one actor (corruptee) makes a demand, either in cash or kind and the other actor (corrupter) supplies the demand. However, the "corrupter" or "corruptee" can be the first to initiate the transaction but the process becomes sealed after each actor carefully assessing the context, content, process and the perceived behavior of the other actor/party involved as well as how the system operates. The model explains that actors involved in this transaction obtain personal and sectional satisfaction which is represented by a single arrow accruing to the actors; however, the net effect is a huge loss to the entire state or organization which is represented by multiple arrows. Thus, while corruption may benefit those who engage in it, the net effect on the entire society in terms of how it affects development, growth and human lives can be devastating. 


\section{Literature Review}

\subsection{Public Sector: Scope and definition}

There is no universally acceptable definition and scope for the public sector, but some definitions are worthy of note. McConnell, Brue and Flynn (2009), suggest that the public sector encapsulates all that is called government. Sapru (2004), also defines the public sector as the composition of human activity that requires common action. Based on these definitions, the public sector is therefore, the realm within which governmental action takes place (Asamoah, Osei-Kojo \& Yeboah-Assiamah, 2013). It is also imperative to mention that the public sector of every state plays a very vital role in the state. Ayee (2007), notes that the public sector has a mammoth impact on the entire populace because it is involved in the provision of goods and services that are imperative for development; it "spearheads economic policy making and management; responsible for the maintenance of law and order" (p. 163). From his definition, the public sector has a wide scope and it generally reflects the totality of institutions and structures that concern itself with the development of a state.

\subsection{Corruption: Conceptual issues, debates and operational definition}

Gould (2001, p.762), posits that, universally, "there are two conflicting and overlapping perspectives on the definition and nature of corruption; these are the moralists and the functionalists." According to Mani (cited in Hager, 1973, p. 199), moralists tend to view and condemn corruption on ethical and moral grounds. The moralist perspective argues that corruption is unethical and could have several negative consequences on the society and economy in general. Corruption, thus, negatively affects growth, and creates hindrances for investors, because it increases the cost of doing business in other countries or overseas (Cuervo-Cazurra, 2006).

On the contrary, functionalist scholars like Nye (1967, p. 427), argues that "corruption is too critical a phenomenon to be left to moralists." Functionalists tend to conceptualize corruption in terms of the actual function that it plays in socio-economic development. They conceive of the potential positive effect that corruption could have on business transactions. Manzetti and Wilson (2007, p. 50) observe that functionalists conceptualize corruption as a "necessary evil to cut bureaucratic red tape, redistribute resources, and sustain socio-economic development." This point has further been advanced by Leff who alludes to the functionalist conception of corruption by suggesting that "bloated, inequitable and statist bureaucracy blocks private investment, therefore, corruption sets up a crude kind of economic efficiency (Leff, 1979 cited in Farazmand, 2001).

Apart from the perspectives, some definitions are worthy of notice. Blackburn et al. (2010, p. 4) define public sector corruption as "an illegal or unauthorized profiteering by public officials by exploiting their positions in public office to maximize their private gains." From the perspective of the principal-agent relationship, officials who are expected to be agents acting on behalf of the principal (public) end up pursuing their personal or sectional interest at the expense of the collective interest of the public or principal (Drury et al., 2006; Gioacchiano \& Franzini, 2008; Bardham, 1997; Nye, 1967). In defining corruption as "the 
abuse of public office for private gain", Drury et al. (2006, p. 122), observe that such gain may be in the form of economic or in terms of increasing an individual's social standing or status. The gain may accumulate to an individual or a faction, or to clients closely related to such individual or group. They argue that corrupt activity includes "bribery, nepotism, theft, and other misappropriation of public resources."

Similarly, Gioacchino and Franzini (2008, p. 293) advance the argument that corruption involves the "mis(use) of public office for private gains, where an official or agent who is a trustee, holding power in trust of the public or principal engages in acts which results in substantial benefits accruing to him or his faction." Nye (1967) points out that "corruption involves an action or performance which deviates from the formal or official requirements or expectations of a public role because of private-regarding (personal, close family, private clique) pecuniary or status gains; or violates rules against the exercise of certain types of private-regarding influence or self-maximizing goal" (p. 149). In the view of Werlin (1973, p.73), corruption is the "diversion of public resources to non-public purposes."

From the discussions above, public sector corruption could be conceptualized as: a well calculated transactional process involving the exploitation of public authority for personal or sectional advancement at the expense of the larger society; that the "beneficiaries" of corruption may be individuals or groups; that corruption may boost a person's or a group's economic position or non-economic status. The process is well calculated because both the 'corruptor' and 'corruptee' would make and receive any offer, after carefully assessing the prevailing circumstances, systems and the other partner or actor in order to avoid any possible challenge of being caught or setup.

It is essential to indicate that the perception and understanding of corruption is context-dependent; this means that different countries, societies and regions tend to perceive corruption differently. In this regard, factors such as history, culture, social, economic, institutional as well as the balance of political and economic opportunities and interest groups shape the understanding of corruption in a society. The position that the understanding of corruption is context dependent is buttressed by Gould (2001, p.761), who asserts that corruption defies a discrete explanation and it varies from constituency to constituency and remains largely contextual. From this perspective, Friedrich (1966, p. 74) defines corruption as "a pattern of behavior which deviates from the norm actually prevalent or believed to prevail in a given context". One implication of conceptualizing corruption as context-dependent is that, what would be regarded as corruption in one context may not be considered as corruption in another context. Consequently, the methods and strategies for fighting corruption in one jurisdiction may not be applicable to another; this calls for the need to designing anti-corruption strategies that suit the peculiarities of the environment.

\subsection{The ubiquity of corruption}

Corruption does not occur within a single organization or state but exists everywhere. Corruption is thus transnational, and its effect is felt globally. Tanzi (1998), corroborates the globalized nature of corruption by suggesting that the 1990s witnessed a great deal of attention devoted to corruption. He argues that "in countries developed and developing, large 
or small, market-oriented or otherwise, governments have fallen because of accusations of corruption, prominent politicians (including presidents of countries and prime ministers) have lost their official positions, and, in some cases, whole political classes have been replaced"(Tanzi 1998, p.559). Even though public sector corruption is a universal phenomenon, the extent of corruption depends on the environment under consideration (Blackburn et al., 2008). Corruption is thus, more prevalent in developing countries than advanced countries, since developing countries appear to provide all the indicators and canons that perpetrate corruption (Manzetti \& Wilson, 2007; Myint, 2000; Hager, 1973).

Myint (2000, p.56), observes that the odor of corruption stinks in societies where there exist some forms of "institutional weaknesses, such as political instability, bureaucratic red tape, and weak legislative and judicial systems." Hager (1973, p.197) reiterates that, the effects and consequences of corruption are likely to be greater in a deprived economy. Similarly, Manzetti and Wilson (2007, p. 963) hypothesized that "weak government institutions allow corrupt politicians to capture government machinery and resources and turn the delivery of public goods into private favors by providing patronage to their clientelistic networks." The authors contend that corrupt governments, in spite of their bad reputation, are able to survive because they have the potential to form patronage or buy votes which in the long run derails the entire system. If corrupt governments are better able to provide favors, citizens may support such governments because of the incentives they supply, even if they are corrupt (ibid).

The foregoing submissions have demonstrated that corruption is prevalent in developing countries than developed countries. In Ghana for instance, Corruption is deemed to be an endemic problem which pervades all spheres and sectors of the economy particularly the police, political parties and public financial management (Chene, 2010). Given the enormity of corruption in developing countries, it is thus imperative that African governments including Ghana take pragmatic steps to curb this menace.

\subsection{Forms and causes of corruption}

Corruption takes different forms and it is usually classified according to the magnitude and the actors involved (Ayee, 2000; Hellman et al., 2000, Chetwynd, 2003). Ayee (2000, p. 39) observes that corruption could be divided into two categories namely: "petty corruption, which is practiced by public servants who may be grossly underpaid, and depend on small rents from the public to feed their families and grand corruption of high public officials who make decisions involving large public contracts". Hellman et al. (2000), suggest that corruption could take the form of administrative corruption, legal corruption and state capture.

There are several causes of corruption, which makes it difficult to explain in a single cause and effect framework (Gould, 2001; Nye, 1967). Corruption occurs across different sectors in different forms and degrees in developing countries. Gould (2001, p. 765) suggests that a major cause of corruption in developing economies including Africa could be linked to the "the nature of the post-colonial state, poverty, cultural factors, the nature of the bureaucratic decision-making system in place, and overseas collusion." The post-colonial state appears to 
have created a congenial atmosphere in which corruption flourished as a result of its weaknesses. Rose-Ackerman (2001, p. 293), points out that "weak states produce widespread corruption, private protection rackets, and the flouting of regulatory and tax laws". Similarly, Manzetti and Wilson (2007) conclude that the prevalence of corruption in developing economies is a product of the dysfunction in the political system. Consequently, a weakened state capacity and the inability of public organizations to check institutional lapses is one cause of corruption.

Ekpo (1979), traces the root causes of corruption in Nigeria to the extended family system. He argues that the extended family system tends to foster stronger ethnic connections which are recipes for corruption. For instance, the relatives or ethnic brothers of a person found guilty of the law usually support the actions of the guilty person even against the law. Similarly, comradeship and sense of belongingness in such societies make families prone to endorsing the corrupt practices of their relatives. Gould and Mukendi (cited in Gould, 2001) contend that the external family system places many responsibilities on officials and are, therefore, tempted to seek extra-legal income in order to attend to family demands. Owing to the burden placed on individuals from the extended family system, they tend to be corrupt.

Another cause of corruption is the lack of trust in top officers, politicians and the entire political system. Mistrust breeds corruption especially at the lower levels, since the exhibition of unethical acts by top bureaucratic and political elites has a rippling effect on subordinates and civic behavior (Morris \& Klesner, 2010; Porta, 2000; Ayee, 2000; Hetherington, 1998). Morris and Klesner (2010) suggest that "low levels of trust nurture corruption. Distrust, thus, fosters a tolerant or acquiescent attitude toward corruption and, by creating the expectation of corrupt behaviors among others; it feeds individual participation in corruption" (p. 1261). This point is also argued by Porta (2000, p. 205) whose study reveals that the "lack of confidence in government actually favors corruption insofar as it transforms citizens into clients and bribers who look for private protection to gain access to decision-makers."

Further, some scholars have argued from the politico-democratic perspective that financing of political parties may have the tendency to breed corruption (Tanzi, 1998; Blechinger, 2005). Blechinger (2005, p. 28) notes that "party corruption is especially problematic in newly democratizing and developing countries where political and economic institutions are not yet secure." When public money is not available for the activities of political parties, enormous pressure builds up on political parties to generate funds and parties may resort to unorthodox means to raise funds. It is against this background that some individuals and organizations advocate state funding of political parties, ostensibly, to ensure loyalty of political parties especially, political parties in government and opposition, and to reduce the temptation or tendency of political parties to be corrupt. The former is controls state resources whilst the latter could easily be influenced or become accomplice in the corruption transaction if pushed beyond the elastic limit.

In addition, poor compensation for public officials makes them susceptible to corrupt practices. Blechinger (2005), observes that the poor state of developing economies places much constraint on governments to properly compensate their public officials. Gould (2001, 
p. 766) corroborates this position by adding that "poor compensation, low pay and poverty level in developing countries is very problematic, and thus contributes greatly to corruption." In a survey by the Centre for Democratic Governance (CDD) in 2000, the causes of corruption in Ghana were linked to low salaries and lack of effective incentive mechanism. Gyekye (2013, p. 89) adds that "the poor economic circumstances of a country may also be noted as a causal factor in the incidence of political corruption. Such economic circumstances may lead to inflation and the erosion of salaries and may in turn depress the material or financial circumstance of public officials (as well as others), making it impossible to make ends meet and ordinary life bearable."

\section{5 Effects of corruption}

Corruption has significant effects on the state and public organizations. In a study by Weitzel and Berns (2006), they analyzed the nexus between corruption, governance, and payments made by foreign and domestic acquirers for taking control of local corporate assets and their observation was that; local shareholder capital is misplaced as a result of corruption. Among the major findings were that there is a "negative relationship between FDI and corruption, which at least partially reflects the wealth lost to domestic asset holders due to corruption" (p. 802). They also found out that high level corruption in the host country is coupled with lower target premiums while local corruption barely gave domestic acquirers an edge over foreign bidders.

Likewise, Cuervo-Cazurra (2006) also examines the impact of corruption on FDI. Among the key findings are that "corruption results in relatively lower FDI from countries that have signed the Organization for Economic Cooperation and Development Convention on Combating Bribery of Foreign Public Officials in International Business Transactions" (p. 810). This implies that economies with strong anti-corruption policies tend to restrict their transactions with economies found to be corrupt. He concludes that corruption generates disincentives for investors as it increases overseas operating cost and further leads to greater uncertainty and risk.

\subsection{Combating corruption}

In the face of widespread corruption and its debilitating effects, Hager (1973, p. 197) opines that "it is a terrible thing... bribery and corruption . . . but what can a few honest people do when it is so deeply rooted in political life? Corruption is conceded to be a universal phenomenon, an affliction to humanity rather than a stigma of nationality." Corruption results in massive societal loss, and so every effort must be made to curb it at all cost. In order to combat corruption Abdulai (2008), observes that no single institution can be used to control corruption. For this reason, efforts to control corruption need to be multi-faceted. The battle against corruption should begin with a strong political will and explicit commitment to eradicate it in all its manifestations. Without political will and commitment by the leadership of a country, political corruption is committed with impunity while administrative corruption becomes the order of the day (Philip, 2002). The lack of political will to prosecute officials who indulge in corruption undermines effort to create a corruption-free society. Caiden (2005), adds that the fight against corruption must not be hypocritical and lackadaisically 
'satisficed' but needs a strong political commitment and will to act, to reinforce deterrent measures and support corruption fighters

Osei-Tutu et al. (2010), suggest that corruption could be tackled through the application of institutional methods (both formal and informal) such as psychological and technical methods. In connection with this, Cavill and Sohail (2005), further suggest that there should be proper guidelines or directives to guide all processes, and discretionary use of power must be limited to the barest minimum (Mawenya, 2007; Goredema, 2002). Ayee (2000), advocates the institutionalization of administrative traps to control the powers and evil tendencies of corrupt officials in the public sector. This must be done in connection with the role of institutional controls and how the formal and informal accountability mechanisms would be put to test (Tanzi, 1998; Gould, 2001). Tanzi (1998), suggests that such controls reflect the position of the political system toward the menace or the general posture of the elites toward corruption.

Generally, the "most effective controls should be those that exist inside the institution"; "honest and effective supervisors, good auditing offices, and clear rules on ethical behavior should be able to discourage or discover corrupt activities; good and transparent procedures should make it easier for these officers to exercise their controls; supervisors should be able to monitor the activities of their subordinates and they should be held accountable for acts of corruption in their offices that go unpunished" ( Tanzi, 1998, p. 575). In addition to such controls, significant importance must be attached to external controls or checks so as to prevent collusion or syndicate. In connection with this, Gould (2001), points out that "a vigilant, well-supported, freely inquiring press provides a means for the public to monitor governmental activities including the extent of corruption in higher places; in several countries, alert newspaper professionals have helped "break" major scandals" (p. 768). Development journalism, which is the extent to which the media/press uses their role to contribute to socio-economic development and expose development-retarding tendencies as well as corrupt officials, should be encouraged. On the other hand, as far as practicable, rent-seeking media houses and prebendalist (stomach-seeking) journalists should be frowned by society. These selfish individuals sycophantly eulogize corrupt officials by providing unflinching support and protection rackets to them in order to obtain monetary and other benefits. It is a serious challenge which affects developing African democracies that needs to be addressed with all the seriousness it deserves.

Additionally, effective implementation of administrative reforms could contribute significantly to curbing corruption. Tanzi (1998, p. 566), points out that, by drastically reforming the way the public sector carries out its functions and activities, the public sector could be positioned to reduce corruption to tolerable limits. Such reforms should target particular sectors in order to be effective. Thus, "the way the state operates and carries out its functions is far more important than the size of public sector activity measured in the traditional way, since particular aspects of governmental activities create a fertile ground for corruption. Consequently, state agencies tasked with fighting corruption need to identify which areas have wider discretionary powers and to tackle them the best possible way; this, therefore, requires an analytical method of probing into sector by sector and function by function to ascertain where there are loopholes. Spector (2005), concludes that the best way 
to tackle corruption in developing countries, including Africa, is through a sector-wide approach or analysis. Some of the sectors that we need to consider include the justice system, education, health care, political parties, public finance, environmental and natural resources, energy, among others.

Further, corruption in Africa could be controlled by fixing rigid and transparent procedures as well as strengthening monitoring mechanisms and executing sanctions in case of violations of the established procedures. In the view of Rose-Ackerman (cited in Salifu, 2008), this involves the encouragement of competition in government and among officials and eschewing monopolistic tendencies. Consequently, the application of competitive bureaucracy may trim down bribery rates, and "thereby discouraging some potentially corrupt officials who balance the risks and benefits of accepting bribes, the lower bribe will also encourage more." (Salifu, 2008, p.295)

Another strategy worth mentioning, in the fight against corruption, is to ensure meritocratic personnel selection as opposed to the spoils system. Rauch and Evans (1999), examine information on 35 developing countries to ascertain the connection between the degree to which the recruitment and promotion of civil servants based on merit would contribute to professionalism and productivity. Their results indicate that the less recruitment and promotion are based on merit, the higher the degree of corruption. Farazmand (2001), corroborates this finding by noting that, "professionalization of public administration has been characterized by an adherence to the merit system, to task specialization, to systems of checks and balances, and to the organizational values of efficiency, economy and effectiveness achieved through political neutrality; it has also meant adherence to professional standards, values, criteria and ethics rather than political or other criteria" ( $p$. 779). Meritocratic recruitment ensures that officials are professionals in their fields, with knowledge of the ethics and ethos of their profession. Thus, they are more likely not to compromise on such standards. It argues that competency must be given priority before selection; hence, nepotism, cronyism, must be avoided at all cost. Above all, there must be constant training and development of the capacity of personnel of the public sector in an attempt to incorporate into them ethical values.

Lastly, Gould (2001) presents a seven-point framework that will help the public sector of African countries curb corruption. The strategies include the following: "commissions of enquiry; purges and wars against indiscipline; codes of ethics and leadership; a free press; tougher laws and enforcement; anticorruption agencies and structural and policy changes" ( $\mathrm{p}$. 68). Brinkerhoff (2001, p. 282) emphasizes the need for accountability in the public service in order to subdue misdeeds and corruption. Accountability can be achieved by insulating anti-corruption agencies from undue external pressures or political intimidation. Public sector organizations must establish internal mechanisms to enhance better reporting systems which would expose all corrupt practices. 


\section{Summary, Conclusion and Recommendations}

This paper has argued that the problem of corruption affects developed and developing countries, but it is more pronounced in developing countries.

Given the multi-faceted nature of corruption, tackling corruption must also be multi-dimensional. Public sector workers, who are to advance the welfare of citizens, must use bureaucratic power to advance the public interest. It therefore, behooves on officials and politicians of public trust to use their authority to serve the course of the public in order to succeed in combating corruption. The literature review reveals that the deep-seated nature of corruption in developing countries is rooted in many factors such as poor compensation for public sector workers and weak institutions. Consequently, it is necessary to consider the multi-dimensional nature of the phenomenon in the fight against corruption.

Furthermore, if the fight against corruption will be successful, public officials and government appointees must have the courage to punish and expose corruption. This implies that the fight against corruption needs to begin from the apex of the political and administrative leadership. Administrative and political leaders must lead by example by living up to ethical standards. Code of conduct and moral suasion could be used to re-orient officials to desist from corrupt practices. Internal whistleblowing must be encouraged in the public sector, and whistleblowers must be honored and motivated but not victimized and intimidated (Morris \& Klesner, 2010; Porta, 2000; Lu \& Gunnison, 2003; Philip, 2002; Gould, 2001; Williams, 1987; Caiden, 2005; Jamieson, 2000; Volkov, 2002).

Additionally, formal and rational mechanisms must be established to ensure proper compensation for public officials. This should take the form of "incentive-based reforms that focus on reducing the benefits or increase the cost of malfeasance". Also, public sector workers should have attractive compensation as low incomes and poor compensation in developing countries make public officials susceptible to corruption. Meritocratic recruitment must be ensured so that nepotism and cronyism would be eschewed. New public management reforms, which advocate market principles such as performance contracts and appraisal, must be instituted to match pay with performance (Gioachinno et al., 2008; Gould, 2001; Rauch \& Evans, 1999; Farazmand, 2001).

Further, state agencies must be empowered and given autonomy to ensure effective monitoring and check institutional lapses that lead to corruption. The media as well as civil society organizations ought to strengthen their watchdog roles in society. Strict and transparent procedures for organizational transactions must be instituted, and such procedures must be clear, known, and predictable and internalized in the society so that bureaucrats do not capitalize on asymmetrical information to exploit their clients or customers (Gould, 2001; Tanzi, 1998; Brinkerhoff, 2001; Kaufman \& Vicente, 2011). 


\section{Macrothink}

Journal of Public Administration and Governance

ISSN 2161-7104

2014, Vol. 4, No. 3

\section{References}

Aleman, U. (2004). The unknown depths of political theory: the case for a multidimensional concept of corruption. Crime, Law and Social Change, 42 (1), 25-34.

Asamoah, K., Osei-Kojo, A., Yeboah-Assiamah, E. (2013). Enhancing public sector productivity in Ghana: A qualitative study. Journal of Public Administration and Governance. 3(3), 22-34. doi: 10.5296/jpag.v3i3.4378

Ayee, J.R.A. (2007).Trends in public sector reforms, in Ayee, J.R.A. (ed.) Ghana at 50: Government and Development.

Ayee, J.R.A (2000). Saints, wizards, demons and systems: explaining the success and failure of public policies and programs. Ghana: University Press.

Bardhan, P. (1997). Corruption and development: a review of issues. Journal of economic literature, 1320-1346.

Barr, A. \& Serra, D. (2010). Corruption and culture: An experimental analysis. Journal of Public Economics, 1-8. doi:10.1016/j. jpubeco.2010.07.006.

Blackburn, K., Bose, N., \& Haque, M., E. (2010). Endogenous corruption in economic development. Journal of Economic Studies, 37 (1), 4-25.

Blechinger, V. (2005). Political parties, in Spector, B.I. (ed.). Fighting corruption in developing countries: strategies and analysis. Bloomfield, CT: Kumarian Press Inc.

Brinkerhoff, D. W. (2005). Accountability and good governance: concepts and issues. in Huque, A. S. \& Zafarullah, H.(eds.). International Development Governance. USA: CRC Press.

Buchanan, J. M., \& Tullock, G. (1962). The calculus of consent: logical foundations of constitutional democracy; Ann Arbor: University of Michigan Press

Caiden, G.E. (2005). Ten major flaws in combating corruption: a cautionary note. in Huque, A. S. \& Zafarullah, H.(eds.). International Development Governance. USA: CRC Press.

Cavill, S. \& Sohail, M. (2005). Improving public urban services through increased accountability. Journal of professional issues in engineering education and practice, American Society of Civil Engineers, 131 (4), 263-73.

Chetwynd, E., Chetwynd, F. \& Spector, B. (2003). Corruption and poverty: a review of recent literature, final report. Washington, DC: Management Systems International.

Coleman, J.S. (1990). Foundations of social theory. Cambridge, MA: Belkap.

Cuervo-Cazurra, A. (2006). Who cares about corruption? Three lenses on the multinational enterprise: politics, corruption and corporate social responsibility. Journal of International Business Studies, 37(6), 807- 822.

Chene, M. (2010). Overview of corruption and anti-corruption in Ghana. Transparency 
International.

Downs, A. (1966). Inside bureaucracy. Boston: Little, Brown \& Co.

Drury, C, Krieckhaus, J \& Lusztig, M. (2006). Corruption, democracy and economic growth. International Political Science Review/ Revue international de science politique, 27(2), 121-136.

Ekpo, M.U (1979), Bureaucratic Corruption in Sub-Saharan Africa, University Press of America, New York, NY

Elster, J. (1983). Sour grapes. Cambridge, UK: Cambridge University Press

Farazmand, A. (2001). Public service ethics and professionalism: A primer for public officials. in Farazmand, A. (ed). Handbook of comparative and development public administration $\left(2^{\text {nd }}\right.$ ed). Marcel Dekker.

Friedman, D. \& Hechter, M. (1988). The contribution of rational choice theory to macro-sociological research. Sociological Theory 6, 201-218.

Friedrich, C. J. (1966). Political pathology. Political Quarterly, 37 (January-March).

Galtung, F. (2001). Transparency international's network to curb global corruption, in Caiden, G. et al. (eds.). Where corruption lives. New Haven, CT: Kumarian Press.

Gioacchino, D. \& Franzini, M. (2008). Bureaucrats' corruption and competition in public administration. European Journal of Law and Economics, 26, 291-306.

Goredema, C. (2002). "Legislating against corruption in Southern African development community", Corruption \& Anti-Corruption in Southern Africa, United Nations Office on Drugs and Crime, Regional Office for Southern Africa

Gould, D.J. (2001). Administrative corruption: Incidence, causes, and remedial strategies. in Farazmand, A. (ed.). Handbook of comparative and development public administration. ( $2^{\text {nd }}$ ed). Marcel Dekker

Gyekye, K. (2013). Philosophy, culture and vision. Accra: Sub-Saharan.

Gyimah-Boadi, E. (2002). Confronting corruption in Ghana and Africa. Briefing paper: Ghana Centre for Democratic Development (CDD-Ghana), 4 (2), 1-6.

Hager, L.M. (1973). Bureaucratic corruption in India: legal control of maladministration. Comparative Political Studies, 6 (2), 197-219.

Hellman, J., Geraint, J. \& Kaufmann, D. (2000). Are foreign investors and multinationals engaging in corrupt practices in transition economies? Report submitted to the World Bank, by the William Davidson Institute, A Stockholm Institute for Transition Economies, Stockholm.

Hetherington, M. (1998). The political relevance of political trust. American Political Science Review, 92 (4), 791-808. 
Jamieson, A. (2000). The anti-mafia: Italy's fight against organized crime. Basingstoke: MacMillan.

Kaufmann, D. \& Vicente, C. P. (2011). Legal corruption. Economics and Politics, 23 (2), 195-219. DOI: 10.1111/j. 1468-0343.20 10.00377

Khramkin, A. (2007). Anti-corruption practices in public procurement, discussion paper submitted to the Government Procurement Institute of the Russian Civil Service Academy.

Leftwich, A. (2005). Changing Configurations of the Developmental State. In Huque, A. S. \& Zafarullah, H. (eds.). International Development Governance. USA: CRC Press

Leff, N.H. (1979). Economic development through bureaucratic corruption. In bureaucratic corruption in M.U Ekpo (ed). Sub-Saharan Africa: Toward a Search for Causes and Consequences. Washington, D.C: University Press of America.

Lu, H. \& Gunnison, E. (2003). Power, corruption and the legal process in China. International Criminal Justice Review, 13.

Manzetti, L. \& Wilson, C.J. (2007). Why do corrupt governments maintain public support? Journal of Comparative Political Studies, 40 (8), 949-97.

Mauro, P. (1998). Corruption and the Composition of Government Expenditure. Journal of Public economics, 69, 263-279.

Mawenya, A.S. (2007). Corruption in public procurement in Sub-Saharan Africa and how to prevent and combat it. Paper presented at the Anti-Corruption Southern Africa Conference.

McConnel, C., Brue S. \& Flynn S. (2009). Microeconomics, 18thedition, McGraw-Hill Irwin,Chapter 16

Mensah, S. (2000). Corporate governance in Africa. Paper presented at the Consultative Meeting on Corporate Governance in Africa, Nairobi, October.

Morris, S.D. and Klesner, J,L. (2010). Corruption and trust: theoretical considerations and evidence from Mexico. Comparative political Studies, 43(10), 1258-1285.

Myint, U. (2000). Corruption: causes, consequences and cures. Asia-Pacific Development Journal, 7(2), 33-57.

Nye, J. (1967). Corruption and political development: A cost-benefit analysis. American Political Science Review, 61, 417-427.

Osei-Tutu, E., Badu, E. \& Owusu-Manu, D. (2010). Exploring corruption practices in public procurement of infrastructural projects in Ghana. International Journal of Managing project in Business, 3 (2), 2010, 236-256.

Pean, J. (1988). L'argent Noir: Corruption et Sous-Development. Fayard Press.

Pepys, M.N. (2005). Justice system. in Spector, B.I. (ed.) Fighting corruption in developing 
countries: strategies and analysis. New Haven, CT: Kumarian Press Inc.

Philip, M. (2002). Conceptualizing Political Corruption in Heidenheimer, A.J and Johnston, M. (eds). Political corruption- concepts and contexts, $\left(3^{\text {rd }}\right.$ ed). London: Transaction Publishers.

Porta, D. (2000). Social capital, beliefs in government and political corruption. In S. J. Pharr \& R. D. Putnam (Eds.). Disaffected democracies: What's troubling the trilateral countries? (pp. 202-230). Princeton, NJ: Princeton University Press.

Rauch, J.E. and Evans, P.B. (1999). Bureaucratic Structure and Bureaucratic Performance in Less Developed Countries. Discussion Paper 99-06, March.University of Carlifornia, San Diego

Reich, R. B. (1983). The next American frontier. New York: Times Books.

Rose-Ackerman, S. (2001). Corruption and development. in Huque, A. S. \& Zafarullah, H.(Eds), International Development Governance. USA: CRC Press.

Rose-Ackerman, S. (1999). Corruption and Governance: causes, consequences, and reform.

New York: Cambridge University Press.

Salifu, A. (2008). Can corruption and economic crime be controlled in developing economies- and if so, is the cost worth it? Journal of Money Laundering Control, 11(3), 273-283.

Sen, A.M. (1977). Rational fools: A critique of the behavioral assumptions of economic theory. Philosophy and public Affairs 4, 318-44.

Shellukindo, W.N. \& Baguma, R. (1993). Ethical standards and behavior in African public services', in Rasheed, S. and Olowu, D. (Eds), Ethics and Accountability in African Public Services, African Association for Public Administration and Management (AAPAM).

Smith, A. (1776). The wealth of nations. New York: Random House

Smith, S.M \& Gerald, S.A. (2010). An introduction to marketing research. London: Mansell

Spector, B. I. (2005). Fighting corruption. In B. I. Spector (ed)., Fighting corruption in developing countries: Strategies and Analysis. Bloomfield: Kumarian.

Stapenhurst, F. \& Langseth, P. (1997). The role of Public Administration in fighting corruption. International Journal of Public Sector Management, 10(5), 311-330.

Ryvkin, D. \& Serra, D. (2011). How corruptible are you? Bribery under uncertainty. Journal of Economic Behavior and Organizations. 81(2), 466-47.

Tanzi, V. (1998). Corruption around the world: causes, consequences, scope and cures. Staff Papers- International Monetary Fund, 45(4), 559-594.

Transparency International. (2013, September 18). Corruption Perception Indexhttp://www.transparency.org/cpi2012/results. 


\section{Macrothink}

Journal of Public Administration and Governance ISSN 2161-7104 2014, Vol. 4, No. 3

Transparency International. (2011). Corruption Perception Index

www.transparency.org/cpi/2011/cpi2011.en.html (accessed October, 17, 2011).

Volkov, V. (2002). Violent entrepreneurs: the use of force in the making of Russian Capitalism. Ithaca, N.Y.: Cornell University Press

UNDP. (2008). Tackling corruption, transforming lives: accelerating human development in Asia and the Pacific', United Nations Development Program, 2008.

Walt, G. \& Gilson, L. (1994). Reforming the Health Sector in Developing Countries- the Central Role of Policy Analysis. Health Policy and Planning, 9, 353-370

World Bank (2003). Ghana 2003 Country Procurement Assessment Report, Ghana Country

Department, World Bank, Washington, DC.

Weitzel, U. \& Berns, S. (2006). Cross-border takeovers, corruption, and related aspects of governance. Journal of International Business Studies, 37 (6), 786-806

Werlin, H. H. (1973). The consequences of corruption: The Ghanaian experience. Political Science Quarterly, 88 (1), 71-85.

Williams, R. (1987). Political Corruption in Africa. Aldershot, England: Gower

Zey, M. (1998). Rational Choice Theory and Organizational Theory: A critique. USA: Sage Publications Inc. 